\title{
YIELD AND QUALITY PERFORMANCES OF ALFALFA (MEDICAGO SATIVA) CULTIVARS SOWN AT VARIOUS DATES UNDER SUB-MEDITERRANEAN ECOLOGICAL CONDITIONS
}

\author{
TURAN, N. \\ Department of Field Crops, Faculty of Agriculture, Siirt University, Siirt, Turkey \\ (e-mail: nturan49@siirt.edu.tr) \\ (Received $8^{\text {th }}$ Aug 2019; accepted $15^{\text {th }}$ Nov 2019)
}

\begin{abstract}
In this study it was aimed to determine the best sowing date and cultivar for the cultivation of alfalfa (Medicago sativa L.) in the Southeastern Anatolian Region of Turkey, using a randomized splitblock design with three replicates. The study was conducted from 2015 to 2017 using alfalfa cultivars of Kayseri, Magnum V, Gea, and Nimet and these cultivars sowed at three different sowing dates March 10, April 5, and April 30, 2015. The mean plant height of the cultivars was $66.04 \mathrm{~cm}$, mean number of main stems was 10.77 number/plant, mean fresh herbage yield was $50020.1 \mathrm{~kg} \mathrm{ha}^{-1}$, mean hay yield was $13509.2 \mathrm{~kg} \mathrm{ha}^{-1}$, mean crude protein yield was $2464.0 \mathrm{~kg} \mathrm{ha}^{-1}$, mean crude protein rate was $17.88 \%$, mean acid detergent fiber (ADF) rate was $34.01 \%$, and mean neutral detergent fiber (NDF) rate was $39.49 \%$. The highest mean plant height, fresh herbage yield, hay yield, and crude protein yield were observed at first and second sowing times. The results clearly indicate that the first and second sowing dates were the most suitable periods for alfalfa planting in the region studied. Additionally, Magnum V cultivar was the highest cultivator for fresh herbage and hay yield.
\end{abstract}

Keywords: alfalfa, sowing dates, varieties, yield, forage quality

\section{Introduction}

Among forage crops, alfalfa (Medicago sativa) has the highest forage yield. Alfalfa's herbage is rich in vitamins and high in protein. Because its herbage and hay are quite beneficial and nutritious for farm animals, alfalfa is known as "the queen of forage crops" (Demiroglu et al., 2008).

The seed-sowing dates for alfalfa planting change from region to region. In coastal regions dominated by a Mediterranean climate, winter sowing is common. On the other hand, in regions having a terrestrial climate such as the Central Anatolian and Eastern Anatolian Regions, sowing are generally performed in spring periods. Some regions in which alfalfa is sown in spring might not produce yield in that first year. Nevertheless, the Southeastern Anatolian Region has the ecological conditions that are suitable for harvesting a considerable yield during the sowing year; however, according to Lowe et al. (1972), the main limiting factors affecting cultivar spreading and growth are precipitation and temperature. Thus, temperate and semitropical regions such as the Mediterranean regions alfalfa can harvest up to eight or nine times per year; however, this yield of alfalfa reduce up to two to three times in colder regions. In another study (Eginlioglu et al., 1996) it was reported that the number of sowings, soil fertility, and climate factors also have an effect on alfalfa yield. In that study, it stated that number of harvest for alfalfa can range from 2 to 4 for Eastern Anatolian and Central Anatolian Region, whereas in the coastal regions harvesting of 7 or 8 can be foreseen.

Saruhan and Kusvuran (2011) have reported for several alfalfa cultivars in the Southeastern Anatolian region that the highest fresh herbage yield (48960 kg ha $\left.{ }^{-1}\right)$ and hay yield $\left(12660 \mathrm{~kg} \mathrm{ha}^{-1}\right)$ was produced by the Elci cultivar, while the highest crude 
protein rate (22.67\%) was obtained from Bilensoy cultivar. Aka and Avcioglu (2003), who investigated the adaptation of seven alfalfa cultivars to the conditions within the Aegean Region, indicated that the height of the main stem varied between 61.56 and $67.50 \mathrm{~cm}$, and that the highest hay yield was obtained from Pioneer-5715 $\left(15730 \mathrm{~kg} \mathrm{ha}^{-}\right.$ ${ }^{1}$ ), whereas it was the lowest for Elci $\left(11780 \mathrm{~kg} \mathrm{ha}^{-1}\right)$. In Similar studies on alfalfa cultivars it showed that hay yield of alfalfa was 11020 - $12660 \mathrm{of} \mathrm{kg} \mathrm{ha}^{-1}, 9820-17970$ of $\mathrm{kg} \mathrm{ha}^{-1}$ and 12910 - 17810 of $\mathrm{kg} \mathrm{ha}^{-1}$ (Sengul and Tahtacioglu, 1996).

Moreover, Yilmaz and Albayrak (2016) sowing the some cultivars such as Bilensoy, Verko, Gea, Prosementi or candidate alfalfa cultivars under Isparta conditions found that the highest crude protein rate was produced by candidate cultivars (17.3 7\%). In that study it was detected that acid detergent fiber (ADF) and neutral detergent fiber (NDF) rates in Bilensoy cultivar were the lowest (34.50 and $42.20 \%$, respectively). Engin and Mut (2017) conducted at to identify some quality parameters in alfalfa fodder and determine hay yield under Yozgat conditions using alfalfa cultivars of Bilensoy, Kayseri, Verko, Gea, Plato, Victoria, Emiliano, Sunter, Nimet and Basbag during the 2013 and 2015. The mean plant height was the highest in Emiliano cultivar $(86.90 \mathrm{~cm})$, whereas it was lowest in Kayseri cultivar $(57.50 \mathrm{~cm})$. Authors detected that total hay yield for two year was 21070.0 and $43305.0 \mathrm{~kg} \mathrm{ha}^{-1}$ for Bilensoy and Sunter, respectively. Again, in that study, the crude protein rate was between $24.20 \%$ and $26.10 \%$ of percent, and the total protein yield was the highest for Sunter $\left(5906.0 \mathrm{~kg} \mathrm{ha}^{-}\right.$ ${ }^{1}$ ), whereas it was the lowest for Gea $\left(3251.0 \mathrm{~kg} \mathrm{ha}^{-1}\right)$.

Alfalfa can be effectively grown for both silage and grain production in Southeastern region of Turkey and thus increasing forage shortage currently encountered will considerably be decreased. The aim of this study was to determine the optimum sowing date for alfalfa under the Southeastern conditions of Turkey, and identify the alfalfa cultivars with the highest quality and yield.

\section{Materials and methods}

This research was conducted in researching and application fields of Siirt University Faculty from 2015 through 2017 (Fig. 1). As plant material we used four cultivars of alfalfa cultivars such as Gea, Magnum V, Kayseri, Nimet obtained from different research institutes and private seed companies in Turkey. These cultivars sown three different sowing dates (March 10, April 05, and April 30, 2015) are more plant height and more resistant to lodging, and the characters of growing is upright. These cultivars in Turkey have been also recommended for the Southern Marmara, Aegean, Thrace, Black Sea, Southeastern and Eastern Anatolia, Central Anatolia, and Mediterranean regions.

According to the randomized split-block trial design with three replications, the whole plot was divided according to the alfalfa cultivars, and subplot parcels were determined by sowing date. There were eight rows in each parcel with $25 \mathrm{~cm}$ between them, and the seeds were sown to a depth of $1-1.5 \mathrm{~cm}$. Three kilograms of seeds were sown over each 0.1 hectare and fertilized with $150 \mathrm{~kg} \mathrm{ha}^{-1}$ diammonium phosphate. The parcel was $2 \mathrm{~m}$ wide and $5 \mathrm{~m}$ long. There were $2 \mathrm{~m}$ of distance between each block and $1 \mathrm{~m}$ between each parcel. The entire experimental field was $19 \mathrm{~m}$ wide and $35 \mathrm{~m}$ long, encompassing a total area of 0.0665 ha. 


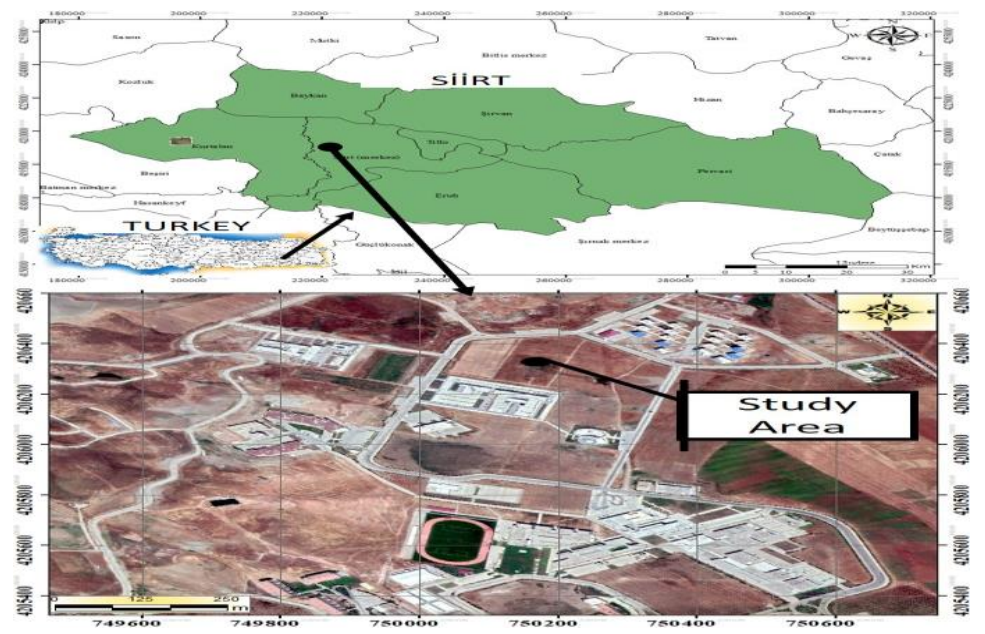

Figure 1. The location of study area

Seeds sown in three different sowing dates (March 10, April 05, and April 30, 2015) had the high performance and harvested during $10-15 \%$ of blooming. 6 rows of plants in the middle of the parcels were harvested after removing one row from the beginning and end of each plot. The processes for pre and post-harvesting were conducted on trial site. Because alfalfa is grown under wet conditions in 2015, five cutting were conducted in the first and second sowing periods, while four cutting were conducted in the third sowing date. In 2016 and 2017, 5 cutting were performed from each sowing period. From each parcel, $0.5 \mathrm{~kg}$ samples were randomly collected, air dried under shadow, placed in an oven set to $78^{\circ} \mathrm{C}$ for $24 \mathrm{~h}$, and dried until there were no further changes in the sample. At this point, the samples were ground and prepared for analyses.

The characteristics measured in the study were plant height $(\mathrm{cm})$, number of main stems (number/plant), fresh herbage yield $\left(\mathrm{kg} \mathrm{ha}^{-1}\right)$, and hay yield $\left(\mathrm{kg} \mathrm{ha}^{-1}\right)$. In addition, crude protein rate, ADF, and NDF were determined by near infrared analysis using the Near Infrared Reflectance Spectroscopy (NIRS) instrument (Hoy et al., 2002).

The 3-year mean values obtained from the study were used for the analysis of variance with JUMP at 0.05 and 0.01 significance levels (SAS, 1998). The differences among the mean values were compared using Fisher's Least Significant Difference multiple comparison test (Gulumser et al., 2006).

\section{Climate characteristics of the research area}

Climate characteristics of the research area are presented in Table 1. The Siirt climate has a long-term precipitation $(713.10 \mathrm{~mm} /$ year $)$, their relative humidity and temperature are $44.73 \%$, and is $16.03{ }^{\circ} \mathrm{C}$, respectively. During this study, the relative humidity was highest in January, and the temperature was generally low. The highest precipitation in 2015 was at $188.00 \mathrm{~mm}$ in October 2015, at $162.40 \mathrm{~mm}$ in January 2016, and at $126.60 \mathrm{~mm}$ in March 2017 (Table 1).

As shown in Table 1, in the time periods of research, temperatures and relative humidity had higher than the long-term mean climate values. In 2015 and 2017, the total precipitation was 668.00 and $540.80 \mathrm{~mm}$, respectively, which were lower than the long-term average of $713.10 \mathrm{~mm}$; however, in 2016, total precipitation at $731.20 \mathrm{~mm}$, which was higher than the long-term average (Table 1). Because region performed in this study are hot and dry, the field was irrigated after each sowing. 


$$
-15618 \text { - }
$$

Table 1. Temperature, precipitation and relative humidity values of the research area (Meteorology Regional Directorate, Siirt)

\begin{tabular}{c|c|c|c|c|c|c|c|c|c|c|c|c}
\hline \multirow{2}{*}{ Months } & \multicolumn{3}{|c|}{ Temperature $\left({ }^{\circ} \mathbf{C}\right)$} & \multicolumn{4}{c|}{ Precipitation $(\mathbf{m m})$} & \multicolumn{3}{c}{ Relative humidity $(\boldsymbol{\%})$} \\
\cline { 2 - 13 } & LYA & $\mathbf{2 0 1 5}$ & $\mathbf{2 0 1 6}$ & $\mathbf{2 0 1 7}$ & LYA & $\mathbf{2 0 1 5}$ & $\mathbf{2 0 1 6}$ & $\mathbf{2 0 1 7}$ & LYA & $\mathbf{2 0 1 5}$ & $\mathbf{2 0 1 6}$ & $\mathbf{2 0 1 7}$ \\
\hline January & 2.60 & 3.86 & 1.69 & 2.95 & 96.80 & 60.80 & 162.40 & 48.80 & 73.30 & 73.98 & 76.04 & 66.11 \\
February & 4.20 & 6.04 & 8.06 & 2.74 & 97.50 & 92.00 & 63.80 & 26.60 & 68.50 & 70.72 & 68.39 & 64.49 \\
March & 8.30 & 9.14 & 10.07 & 9.54 & 111.10 & 125.00 & 135.60 & 126.60 & 60.4 & 63.19 & 62.35 & 64.16 \\
April & 13.70 & 13.72 & 16.70 & 14.00 & 104.70 & 53.20 & 66.80 & 124.60 & 50.40 & 55.48 & 47.45 & 59.18 \\
May & 19.30 & 20.42 & 19.90 & 19.55 & 62.00 & 26.80 & 64.60 & 74.60 & 41.50 & 42.99 & 48.92 & 51.62 \\
June & 26.00 & 26.87 & 26.52 & 26.94 & 8.70 & 3.60 & 20.40 & 0.0 & 24.10 & 27.79 & 32.63 & 29.44 \\
July & 30.60 & 32.09 & 31.37 & 32.28 & 1.60 & 0.00 & 2.40 & 0.0 & 18.10 & 19.56 & 24.48 & 18.99 \\
August & 30.10 & 31.37 & 32.28 & 31.94 & 0.90 & 2.40 & 0.20 & 0.40 & 17.20 & 22.55 & 20.55 & 18.99 \\
September & 25.10 & 28.13 & 24.86 & 28.31 & 4.90 & 1.60 & 18.80 & 0.0 & 24.00 & 23.14 & 29.82 & 19.22 \\
October & 17.90 & 18.54 & 19.49 & 18.35 & 49.10 & 188.00 & 40.20 & 18.40 & 45.30 & 59.23 & 37.10 & 35.15 \\
November & 10.40 & 10.56 & 10.33 & 11.13 & 81.40 & 56.80 & 51.80 & 73.40 & 57.10 & 64.76 & 49.82 & 64.44 \\
December & 4.80 & 5.00 & 3.35 & 7.95 & 94.40 & 57.80 & 104.2 & 47.40 & 56.9 & 61.75 & 72.92 & 65.29 \\
Total/Average & 16.08 & 17.15 & 17.05 & 17.14 & 713.10 & 668.00 & 731.20 & 540.80 & 44.73 & 48.76 & 47.54 & 46.42 \\
\hline
\end{tabular}

LYA: Long years' average (1960-2017)

\section{Soil properties in the research area}

The results of the soil analysis of research area performed by Siirt University Science and Technology Application and Research Center Laboratory are presented in Table 2.

The soil analysis showed that the soil of research field had a neutral $\mathrm{pH}$, was highly calcareous, non saline, had low organic matter and plant-available phosphorus, and had sufficient potassium, copper and iron but was low in zinc and manganese concentrate (Table 2).

Table 2. Soil analysis results of the research area

\begin{tabular}{|c|c|c|c|c|c|c|c|c|c|c|c|c|}
\hline \multirow[b]{2}{*}{$\mathbf{p H}$} & \multirow{2}{*}{$\begin{array}{c}\text { Salt } \\
\text { ds/m }\end{array}$} & \multirow{2}{*}{$\begin{array}{c}\text { Lime } \\
\left(\mathrm{CaCO}_{3}\right) \\
(\%)\end{array}$} & \multirow{2}{*}{$\begin{array}{c}\text { Organic } \\
\text { matter } \\
(\%)\end{array}$} & \multirow{2}{*}{\begin{tabular}{|c|}
$\mathbf{P}$ \\
$\left(\mathbf{P}_{2} \mathbf{O}_{5}\right)$ \\
$\mathrm{kg} \mathrm{ha}^{-1}$ \\
\end{tabular}} & \multirow{2}{*}{$\begin{array}{c}\mathbf{K} \\
\left(\mathbf{K}_{2} \mathbf{O}\right) \\
\mathbf{p p m}\end{array}$} & \multirow{2}{*}{$\begin{array}{c}\text { Fe } \\
\text { ppm }\end{array}$} & \multirow{2}{*}{$\begin{array}{c}\mathrm{Cu} \\
\mathrm{ppm}\end{array}$} & \multirow{2}{*}{$\begin{array}{c}\mathrm{Zn} \\
\mathbf{p p m}\end{array}$} & \multirow{2}{*}{$\begin{array}{c}\text { Mn } \\
\text { ppm }\end{array}$} & \multicolumn{3}{|c|}{ Soil (\%) } \\
\hline & & & & & & & & & & Sand & Clay & Silt \\
\hline 7.21 & 1.47 & 16.30 & 1.96 & 24.4 & 620 & 14.07 & 5.89 & 1.13 & 22.71 & 36 & 44 & 20 \\
\hline
\end{tabular}

Soil analyses were conducted at the Siirt University Science and Technology Application and Research Center Directorate (2015).

\section{Results and discussion}

\section{Plant height}

The plant height of the alfalfa cultivars sown at different dates under Siirt conditions and the results of their multiple comparison are presented in Table 3. The results of the effect of cultivar, sowing date, and sowing date $\mathrm{x}$ year interaction for the mean plant height of the alfalfa were significant at $\mathrm{p}<0.05$, while those of year and cultivar $\mathrm{x}$ year interaction were significant at $\mathrm{p}<0.01$. Effects of interactions of cultivar $\mathrm{x}$ sowing date and the cultivar $\mathrm{x}$ sowing date $\mathrm{x}$ year were not significant. 
When the findings were examined (Table 3), the mean plant height of the cultivars in the study ranged from 62.62 to $67.91 \mathrm{~cm}$. The mean plant height were the highest for cultivars of Kayseri $(67.91 \mathrm{~cm})$, Gea $(67.35 \mathrm{~cm})$, and Magnum V $(66.28 \mathrm{~cm})$, whereas Nimet cultivar was the lowest for this characteristics $(62.62 \mathrm{~cm})$. The mean plant height according to sowing dates was $66.04 \mathrm{~cm}$. In the first and second sowing dates, plant height was the highest (67.81 and $67.76 \mathrm{~cm}$, respectively). However, it was $62.55 \mathrm{~cm}$ in plants from the third sowing date. The mean plant heights in different years were 52.39, 71.96 , and $73.77 \mathrm{~cm}$ for years of 2015,2016 , and 2017, respectively.

In the current study, varieties investigated were significantly affected form interaction of sowing date $\mathrm{x}$ year, showing that there are differences based on sowing dates. Through the years, the height of plants was the lowest at first planting period, but there were a ongoing increase in the following years. Thus, the height of plant was affected form variety $\mathrm{x}$ year interaction. For example, Magnum V was the lowest for plant height at first year of trial, but there was a significant increase for plant height in the following years compared with the other cultivars.

Table 3. Effect of cultivar and sowing date on plant height $(\mathrm{cm})$

\begin{tabular}{|c|c|c|c|c|c|c|}
\hline \multirow{2}{*}{ Years } & \multirow{2}{*}{ Sowing dates } & \multicolumn{5}{|c|}{ Varieties } \\
\hline & & Kayseri & Magnum V & Gea & Nimet & Variety mean \\
\hline \multirow{4}{*}{2015} & $1^{\text {st }}$ sowing date & 60.93 & 53.03 & 60.17 & 60.37 & $58.63^{\mathrm{B}}$ \\
\hline & $2^{\text {nd }}$ sowing date & 48.67 & 55.23 & 55.17 & 55.67 & $53.69^{\text {в }}$ \\
\hline & $3^{\text {rd }}$ sowing date & 44.70 & 42.40 & 49.27 & 43.17 & $44.88^{\mathrm{C}}$ \\
\hline & Mean & $51.43^{\mathrm{E}}$ & $50.22^{\mathrm{E}}$ & $54.87^{\mathrm{E}}$ & $53.07^{\mathrm{E}}$ & $52.40^{\mathrm{B}}$ \\
\hline \multirow{4}{*}{2016} & $1^{\text {st }}$ sowing date & 74.27 & 69.13 & 70.93 & 66.40 & $70.18^{\mathrm{A}}$ \\
\hline & $2^{\text {nd }}$ sowing date & 73.93 & 71.00 & 72.60 & 75.47 & $73.25^{\mathrm{A}}$ \\
\hline & $3^{\text {rd }}$ sowing date & 76.60 & 72.06 & 70.80 & 70.33 & $72.44^{\mathrm{A}}$ \\
\hline & Mean & $74.93^{\mathrm{A}-\mathrm{C}}$ & $70.73^{\mathrm{C}}$ & $71.44^{\mathrm{BC}}$ & $70.73^{\mathrm{C}}$ & $71.95^{\mathrm{A}}$ \\
\hline \multirow{4}{*}{2017} & $1^{\text {st }}$ sowing date & 79.43 & 75.87 & 79.30 & 63.93 & $74.63^{\mathrm{A}}$ \\
\hline & $2^{\text {nd }}$ sowing date & 73.03 & 87.13 & 80.20 & 65.00 & $76.34^{\mathrm{A}}$ \\
\hline & $3^{\text {rd }}$ sowing date & 79.67 & 70.70 & 67.73 & 63.23 & $70.33^{\mathrm{A}}$ \\
\hline & Mean & $77.37^{\mathrm{AB}}$ & $77.90^{\mathrm{A}}$ & $75.74^{\mathrm{A}-\mathrm{C}}$ & $64.05^{\mathrm{D}}$ & $73.76^{\mathrm{A}}$ \\
\hline \multirow{4}{*}{ Mean years } & $1^{\text {st }}$ sowing date & 71.54 & 66.01 & 70.13 & 63.56 & $67.81^{\mathrm{A}}$ \\
\hline & $2^{\text {nd }}$ sowing date & 65.21 & 71.12 & 69.32 & 65.38 & $67.76^{\mathrm{A}}$ \\
\hline & $3^{\text {rd }}$ sowing date & 66.99 & 61.72 & 62.60 & 58.91 & $62.55^{\mathrm{B}}$ \\
\hline & Mean of mean & $67.91^{\mathrm{A}}$ & $66.28^{\mathrm{A}}$ & $67.35^{\mathrm{A}}$ & $62.62^{\mathrm{B}}$ & 66.04 \\
\hline $\mathrm{CV}(\%)$ & \multicolumn{6}{|c|}{9.50} \\
\hline $\mathrm{LSD}_{\text {variety }}$ & \multicolumn{6}{|c|}{$3.40^{*}$} \\
\hline $\mathrm{LSD}_{\text {sowing date }}$ & \multicolumn{6}{|c|}{$3.81^{*}$} \\
\hline $\mathrm{LSD}_{\text {year }}$ & \multicolumn{6}{|c|}{$3.81^{* *}$} \\
\hline $\mathrm{LSD}_{\text {variety } \mathrm{x} \text { year }}$ & \multicolumn{6}{|c|}{$5.92^{* *}$} \\
\hline $\mathrm{LSD}_{\text {sowing date } \mathrm{x} \text { year }}$ & \multicolumn{6}{|c|}{$6.62^{*}$} \\
\hline 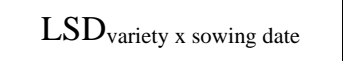 & \multicolumn{6}{|c|}{$\mathrm{ns}$} \\
\hline $\mathrm{LSD}_{\text {variety } \mathrm{x} \text { sowing date } \mathrm{x} \text { year }}$ & \multicolumn{6}{|c|}{ ns } \\
\hline
\end{tabular}

The difference between the averages indicated by the same letter in the same group is not statistically significant. *:Significant difference at $\mathrm{P}<0.05$ level, ${ }^{* *}$ :Significant difference at $\mathrm{P}<0.01$ level, CV: variation coefficient, LSD: least significant difference, NS: non-significant. 
The results obtained in this study are similar those of plant height taken from another study done in Izmir and Selcuk regions in Turkey $(61.56-67.50 \mathrm{~cm}$ ) (Aka and Avcioglu, 1999); however, the plant heights in our study were higher than those observed in the studies done in the Eastern Anatolian Region (54.7) (Cacan et al., 2018), Southeastern Anatolian Region (40.1 - 49.7) (Saruhan and Kusvuran, 2011), Kirşehir (53.91 - $63.47 \mathrm{~cm}$ ) (Inal, 2015). But our findings for plant height were lower than those from the studies in the Aegean region (Kavut et al., 2014) and Yozgat (Engin and Mut, 2017) at $73.97-81.50$ and $57.50-86.90 \mathrm{~cm}$, respectively.

\section{Number of main stems}

According to the mean number of main stems in the alfalfa cultivars sown at different dates and their multiple comparisons (Table 4), effect of cultivar, sowing date, and cultivar $\mathrm{x}$ sowing date $\mathrm{x}$ year on the number of main stems were significant at $p<0.05$; again, year and cultivar $x$ year were significant at $p<0.01$. Nonetheless, effect of sowing date $x$ year and cultivar $x$ sowing date were not statistically significant. When these results were examined, we observed that the mean number of main stems in the cultivars ranged between 10.33 and 11.05 number/plant, and the differences in the mean number of main stems in the cultivars were not statistically significant, except for Nimet cultivar (Table 4).

Table 4. Effect of cultivar and sowing date on number of main stem (number/plant)

\begin{tabular}{|c|c|c|c|c|c|c|}
\hline \multirow{2}{*}{ Years } & \multirow{2}{*}{ Sowing dates } & \multicolumn{5}{|c|}{ Varieties } \\
\hline & & Kayseri & Magnum V & Gea & Nimet & Variety mean \\
\hline \multirow{4}{*}{2015} & $1^{\text {st }}$ sowing date & $7.73 \mathrm{mn}$ & $6.97^{n}$ & $9.33^{\mathrm{j}-1}$ & $8.83^{\mathrm{k}-\mathrm{m}}$ & 8.21 \\
\hline & $2^{\text {nd }}$ sowing date & $10.36^{\mathrm{h}-\mathrm{j}}$ & $7.83 \mathrm{mn}$ & $9.83^{1-k}$ & $8.63^{\mathrm{k}-\mathrm{m}}$ & 9.16 \\
\hline & $3^{\text {rd }}$ sowing date & $6.83^{\mathrm{n}}$ & $7.10^{\mathrm{n}}$ & $8.16^{1-n}$ & $8.1^{1-n}$ & 7.55 \\
\hline & Mean & $8.31^{\mathrm{d}}$ & $7.30^{\mathrm{e}}$ & $9.11^{\mathrm{d}}$ & $8.52^{\mathrm{d}}$ & $8.31^{\mathrm{B}}$ \\
\hline \multirow{4}{*}{2016} & $1^{\text {st }}$ sowing date & $11.86^{\mathrm{c}-\mathrm{g}}$ & $12.53^{\mathrm{a}-\mathrm{f}}$ & $11.33^{\mathrm{d}-\mathrm{h}}$ & $11.46^{\mathrm{d}-\mathrm{h}}$ & 11.80 \\
\hline & $2^{\text {nd }}$ sowing date & $12.26^{\mathrm{b}-\mathrm{f}}$ & $12.73^{\mathrm{a}-\mathrm{d}}$ & $12.06^{\mathrm{b}-\mathrm{g}}$ & $10.73^{g-j}$ & 11.95 \\
\hline & $3^{\text {rd }}$ sowing date & $11.73^{\mathrm{d}-\mathrm{h}}$ & $11.60^{\mathrm{d}-\mathrm{h}}$ & $11.60^{\mathrm{d}-\mathrm{h}}$ & $11.66^{\mathrm{d}-\mathrm{h}}$ & 11.65 \\
\hline & Mean & $11.95^{\mathrm{a}-\mathrm{c}}$ & $12.28^{\mathrm{ab}}$ & $11.66^{\mathrm{bc}}$ & $11.28^{\mathrm{c}}$ & $11.80^{\mathrm{A}}$ \\
\hline \multirow{4}{*}{2017} & $1^{\text {st }}$ sowing date & $12.63^{\mathrm{a}-\mathrm{e}}$ & $12.53^{\mathrm{a}-\mathrm{f}}$ & $12.50^{\mathrm{a}-\mathrm{f}}$ & $11.20^{\mathrm{e}-1}$ & 12.21 \\
\hline & $2^{\text {nd }}$ sowing date & $11.76^{\mathrm{d}-\mathrm{h}}$ & $13.93^{\text {a }}$ & $13.36^{a b}$ & $11.16^{\mathrm{f}-1}$ & 12.55 \\
\hline & $3^{\text {rd }}$ sowing date & $13.30^{\mathrm{a}-\mathrm{c}}$ & $11.83^{\mathrm{d}-\mathrm{g}}$ & $11.26^{\mathrm{e}-1}$ & $11.20^{\mathrm{e}-1}$ & 11.90 \\
\hline & Mean & $12.56^{\mathrm{a}}$ & $12.76^{\mathrm{a}}$ & $12.37^{\mathrm{ab}}$ & $11.18^{\mathrm{c}}$ & $12.22^{\mathrm{A}}$ \\
\hline \multirow{4}{*}{ Mean years } & $1^{\text {st }}$ sowing date & 10.74 & 10.68 & 11.05 & 10.50 & $10.74^{\mathrm{AB}}$ \\
\hline & $2^{\text {nd }}$ sowing date & 11.46 & 11.50 & 11.75 & 10.17 & $11.22^{\mathrm{A}}$ \\
\hline & $3^{\text {rd }}$ sowing date & 10.62 & 10.18 & 10.34 & 10.32 & $10.36^{\mathrm{B}}$ \\
\hline & Mean of mean & $10.94^{\mathrm{A}}$ & $10.78^{\mathrm{AB}}$ & $11.05^{\mathrm{A}}$ & $10.33^{\mathrm{B}}$ & 10.78 \\
\hline $\mathrm{CV}(\%)$ & \multicolumn{6}{|c|}{8.30} \\
\hline $\mathrm{LSD}_{\text {variety }}$ & \multicolumn{6}{|c|}{$\begin{array}{l}8.30 \\
0.48^{*}\end{array}$} \\
\hline $\mathrm{LSD}_{\text {sowing date }}$ & \multicolumn{6}{|c|}{$0.60^{*}$} \\
\hline LSD $_{\text {year }}$ & \multicolumn{6}{|c|}{$0.60^{* *}$} \\
\hline $\mathrm{LSD}_{\text {variety } \mathrm{x} \text { year }}$ & \multicolumn{6}{|c|}{$0.84^{* *}$} \\
\hline $\mathrm{LSD}_{\text {sowing date } x \text { year }}$ & \multicolumn{6}{|c|}{$\mathrm{ns}$} \\
\hline $\mathrm{LSD}_{\text {variety } x \text { sowing date }}$ & \multirow{2}{*}{\multicolumn{6}{|c|}{$\begin{array}{c}\mathrm{ns} \\
146^{*}\end{array}$}} \\
\hline LSD $_{\text {variety } x}$ sowing date $x$ year & & & & & & \\
\hline
\end{tabular}

The difference between the averages indicated by the same letter in the same group is not statistically significant, ":Significant difference at $\mathrm{P}<0.05$ level, ${ }^{* *}$ :Significant difference at $\mathrm{P}<0.01$ level, CV: variation coefficient, LSD: least significant difference, NS: non-significant. 
There were no differences between the first and second sowing dates for number of main stems, except for third sowing date. The highest mean number of main stems was 11.22 number/plant from the second sowing date, and the lowest was 10.36 number/plant observed from the third sowing date. The mean number of main stem in different sowing years was 8.31, 11.80, and 12.22 number/plant, respectively, for years of 2015, 2016, and 2017. The differences in the mean number of main stems in the alfalfa cultivars changed throughout the years, and cultivar $\mathrm{x}$ year interaction was significant as statistical. Magnum V cultivar had an increase for numbers of main stems over the years and it was the highest compared to the other cultivars at the end of the year.

The values obtained for the number of main stems were lower than those obtained in the studies performed by Turan et al. (2017), Demiroglu et al. (2008), Kavut et al. (2014), Petkova et al. (2003) and Seker et al. (2003), but higher than those from obtained in the study performed by Inal (2015).

\section{Fresh herbage yield}

The difference in mean fresh herbage yield from the alfalfa cultivars sown at different dates and their multiple comparisons indicated that effect of sowing date $\mathrm{x}$ year were statistically significant at $p<0.05$, and sowing date and years were significant at $\mathrm{p}<0.01$. On the other hand, the differences in mean fresh herbage yields for cultivar, cultivar x year, cultivar $\mathrm{x}$ sowing date, and cultivar $\mathrm{x}$ sowing date $\mathrm{x}$ year were not statistically significant (Table 5).

Mean fresh herbage yields in different sowing dates ranged between 42948.0 and $54893.3 \mathrm{~kg} \mathrm{ha}^{-1}$. There were no differences between the first and second sowing dates whereas, there was a difference in the third sowing date. The mean fresh herbage yield according to year was $36549.1,55548.0$, and $57963.3 \mathrm{~kg} \mathrm{ha}^{-1}$, respectively, for 2015 , 2016, and 2017. Cultivars had different fresh herbage yields according to different sowing dates, and the ones with lower fresh herbage yields had increasingly higher yields in the following years; however, among the sowing dates used, the second had the highest fresh herbage yield. There were statistically significant differences for year $\mathrm{x}$ sowing date (Table 5).

The fresh herbage yields detected in this study were lower than the results reported by Demiroglu et al. (2008), Kavut et al. (2014), Avci et al. (2013), Petkova et al. (2003), Aka and Avcioglu (1999), and Seker et al. (2003). However, our findings for fresh herbage yield were higher than the values reported by Turan et al. (2017), Cacan et al. (2018) and Inal (2015), and it was in accordance with findings Saruhan and Kusvuran (2011).

\section{Hay yield}

Table 6 illustrates the values for mean hay yield of alfalfa cultivars sown on different dates. These values clearly show that effect of cultivar $\mathrm{x}$ sowing date on mean hay yield is statistically significant at $\mathrm{p}<0.05$, and that sowing date and years are statistically significant at $\mathrm{p}<0.01$.

In the present study, the effect of the cultivars, cultivar $\mathrm{x}$ year, sowing date $\mathrm{x}$ year, and cultivar $\mathrm{x}$ sowing date $\mathrm{x}$ year on mean hay yield was not statistically significant. While the fresh herbage and hay yield of the cultivars examined in the study (Kayseri, Magnum V and Gea) were higher than the second year; the values of the second year was higher than values of the third year. 


$$
-15622 \text { - }
$$

Table 5. Effect of cultivar and sowing date on fresh herbage yield $\left(\mathrm{kg} \mathrm{ha}^{-1}\right)$

\begin{tabular}{|c|c|c|c|c|c|c|}
\hline \multirow{2}{*}{ Years } & \multirow{2}{*}{ Sowing dates } & \multicolumn{5}{|c|}{ Varieties } \\
\hline & & Kayseri & Magnum V & Gea & Nimet & Variety mean \\
\hline \multirow{4}{*}{2015} & $1^{\text {st }}$ sowing date & 46280.0 & 33360.0 & 47136.7 & 44886.7 & $42915.8^{\mathrm{B}}$ \\
\hline & $2^{\text {nd }}$ sowing date & 40853.3 & 39040.0 & 50166.7 & 49756.7 & $44954.1^{\text {В }}$ \\
\hline & $3^{\text {rd }}$ sowing date & 21386.7 & 25353.3 & 23613.3 & 16756.7 & $21777.5^{\mathrm{C}}$ \\
\hline & Mean & 36173.3 & 32584.4 & 40305.5 & 37133.3 & $36549.1^{\mathrm{B}}$ \\
\hline \multirow{4}{*}{2016} & $1^{\text {st }}$ sowing date & 51860.0 & 57033.3 & 57976.7 & 55910.0 & $55695.0^{\mathrm{A}}$ \\
\hline & $2^{\text {nd }}$ sowing date & 54503.3 & 62783.3 & 60710.0 & 60086.7 & $59520.8^{\mathrm{A}}$ \\
\hline & $3^{\text {rd }}$ sowing date & 55320.0 & 46850.0 & 50496.7 & 53046.7 & $51428.3^{\mathrm{AB}}$ \\
\hline & Mean & 53894.4 & 55555.5 & 56394.4 & 56347.8 & $55548.0^{\mathrm{A}}$ \\
\hline \multirow{4}{*}{2017} & $1^{\text {st }}$ sowing date & 59473.3 & 57813.3 & 60683.3 & 54216.7 & $58046.7^{\mathrm{A}}$ \\
\hline & $2^{\text {nd }}$ sowing date & 55960.0 & 67713.3 & 62176.7 & 54970.0 & $60205.0^{\mathrm{A}}$ \\
\hline & $3^{\text {rd }}$ sowing date & 60366.7 & 52770.0 & 53670.0 & 55746.7 & $55638.3^{\mathrm{A}}$ \\
\hline & Mean & 58600.0 & 59432.2 & 58843.3 & 54977.8 & $57963.3^{\mathrm{A}}$ \\
\hline \multirow{4}{*}{ Mean years } & $1^{\text {st }}$ sowing date & 52537.8 & 49402.2 & 55265.6 & 51671.1 & $52219.1^{\mathrm{A}}$ \\
\hline & $2^{\text {nd }}$ sowing date & 50438.9 & 56512.2 & 57684.5 & 54937.8 & $54893.3^{\mathrm{A}}$ \\
\hline & $3^{\text {rd }}$ sowing date & 45691.1 & 41657.8 & 42593.3 & 41850.0 & $42948.0^{\mathrm{B}}$ \\
\hline & Mean of mean & 49555.9 & 49190.7 & 51847.8 & 49486.3 & 50020.1 \\
\hline $\mathrm{CV}(\%)$ & \multicolumn{6}{|c|}{14.00} \\
\hline $\mathrm{LSD}_{\text {variety }}$ & \multicolumn{6}{|c|}{ ns } \\
\hline $\mathrm{LSD}_{\text {sowing date }}$ & \multicolumn{6}{|c|}{ ns } \\
\hline $\mathrm{LSD}_{\text {year }}$ & \multicolumn{6}{|c|}{$562.29^{* *}$} \\
\hline $\mathrm{LSD}_{\text {variety } \mathrm{x} \text { year }}$ & \multicolumn{6}{|c|}{$\mathrm{ns}$} \\
\hline $\mathrm{LSD}_{\text {sowing date } \mathrm{x} \text { year }}$ & \multicolumn{6}{|c|}{$973.74^{*}$} \\
\hline $\mathrm{LSD}_{\text {variety x sowing date }}$ & \multicolumn{6}{|c|}{$\mathrm{ns}$} \\
\hline $\mathrm{LSD}_{\text {variety } \mathrm{x} \text { sowing date } \mathrm{x} \text { year }}$ & \multicolumn{6}{|c|}{$\mathrm{ns}$} \\
\hline
\end{tabular}

The difference between the averages indicated by the same letter in the same group is not statistically significant, ${ }^{*}$ :Significant difference at $\mathrm{P}<0.05$ level, ${ }^{* *}$ :Significant difference at $\mathrm{P}<0.01$ level, CV: variation coefficient, LSD: least significant difference, NS: non-significant.

The fresh herbage and hay yield were 37133.3 - $9139.5 \mathrm{~kg} \mathrm{ha}^{-1}$ in the first year, in the second year increased to 56347.7 - $15946.0 \mathrm{~kg} \mathrm{ha}^{-1}$, then decreased to 54977.7 $15534.6 \mathrm{~kg} \mathrm{ha}^{-1}$ in the final year. This situation is believed to be related to the characteristic differences in cultivars and their different responses to varying ecological conditions.

The mean hay yields of the groups from the different sowing dates ranged from 11932.7 to $14589.1 \mathrm{~kg} \mathrm{ha}^{-1}$, with the highest hay yield observed from the second sowing date and the lowest from the third sowing date. Mean hay yields were 8 635.7, 15 557.4, and $16334.7 \mathrm{~kg} \mathrm{ha}^{-1}$, respectively, for years of 2015, 2016, and 2017. Considering the three-year values together with the year of the sowing, fresh herbage and hay yield values had an similar increase. However, the hay yield in second sowing date was the highest, indicating that cultivar $\mathrm{x}$ sowing date interaction lead to these differences (Table 6).

In the present study, the hay yield were higher than that of values reported in the Eastern Anatolian Region (13154.0 and $12270.0 \mathrm{~kg} \mathrm{ha}^{-1}$ ) (Turan et al., 2017; Cacan et 
al., 2018) and in Europe, North Africa, and the United States (14200.0 kg ha $\left.{ }^{-1}\right)$ (Pecetti et al., 2008). However, our findings for hay yield were lower than those observed in the study done in Bornova and Odemiş in Turkey (Demiroglu et al., 2008), with yields ranging from 18920.0 to $24740.0 \mathrm{~kg} \mathrm{ha}^{-1}$.

Table 6. Effect of cultivar and sowing date on dry herbage yield $\left(\mathrm{kg} \mathrm{ha}^{-1}\right)$

\begin{tabular}{|c|c|c|c|c|c|c|}
\hline \multirow{2}{*}{ Years } & \multirow{2}{*}{ Sowing dates } & \multicolumn{5}{|c|}{ Varieties } \\
\hline & & Kayseri & Magnum V & Gea & Nimet & Variety mean \\
\hline \multirow{4}{*}{2015} & $1^{\text {st }}$ sowing date & 10689.8 & 8006.5 & 10614.0 & 11063.8 & 10093.5 \\
\hline & $2^{\text {nd }}$ sowing date & 8469.3 & 9273.5 & 11891.7 & 12081.7 & 10429.0 \\
\hline & $3^{\text {rd }}$ sowing date & 5323.1 & 5991.9 & 5950.3 & 4272.9 & 5384.5 \\
\hline & Mean & 8160.7 & 7757.3 & 9485.3 & 9139.5 & $8635.7^{\mathrm{B}}$ \\
\hline \multirow{4}{*}{2016} & $1^{\text {st }}$ sowing date & 14536.3 & 15613.5 & 15696.1 & 15173.1 & 15254.7 \\
\hline & $2^{\text {nd }}$ sowing date & 15155.2 & 17522.5 & 17006.4 & 17240.2 & 16731.1 \\
\hline & $3^{\text {rd }}$ sowing date & 15512.2 & 13401.3 & 14407.0 & 15424.7 & 14686.3 \\
\hline & Mean & 15067.9 & 15512.4 & 15703.2 & 15946.0 & $15557.4^{\mathrm{A}}$ \\
\hline \multirow{4}{*}{2017} & $1^{\text {st }}$ sowing date & 17050.9 & 15975.5 & 18058.5 & 15593.5 & 16669.6 \\
\hline & $2^{\text {nd }}$ sowing date & 14471.3 & 19060.9 & 17890.5 & 15005.9 & 16607.1 \\
\hline & $3^{\text {rd }}$ sowing date & 16819.0 & 13232.9 & 16852.8 & 16004.4 & 15727.3 \\
\hline & Mean & 16113.7 & 16089.8 & 17600.6 & 15534.6 & $16334.7^{\mathrm{A}}$ \\
\hline \multirow{4}{*}{ Mean years } & $1^{\text {st }}$ sowing date & $14092.3^{\mathrm{A}-\mathrm{C}}$ & $13198.5^{\mathrm{B}-\mathrm{D}}$ & $14789.5^{\mathrm{AB}}$ & $13943.5^{\mathrm{A}-\mathrm{C}}$ & $14006.0^{\mathrm{A}}$ \\
\hline & $2^{\text {nd }}$ sowing date & $12698.6^{\mathrm{CD}}$ & $15285.6^{\mathrm{A}}$ & $15596.2^{\mathrm{A}}$ & $14776.0^{\mathrm{AB}}$ & $14589.1^{\mathrm{A}}$ \\
\hline & $3^{\text {rd }}$ sowing date & $12551.4^{\mathrm{C}-\mathrm{E}}$ & $10875.3^{\mathrm{E}}$ & $12403.4^{\mathrm{C}-\mathrm{E}}$ & $11900.7^{\mathrm{DE}}$ & $11932.7^{\mathrm{B}}$ \\
\hline & Mean of mean & 13114.1 & 13119.8 & 14263.0 & 13540.0 & 13509.2 \\
\hline $\mathrm{CV}(\%)$ & \multicolumn{6}{|c|}{13.99} \\
\hline $\mathrm{LSD}_{\text {variety }}$ & \multicolumn{6}{|c|}{$\mathrm{ns}$} \\
\hline $\mathrm{LSD}_{\text {sowing date }}$ & \multicolumn{6}{|c|}{$141.12^{* *}$} \\
\hline $\mathrm{LSD}_{\text {year }}$ & \multicolumn{6}{|c|}{$141.12^{* *}$} \\
\hline $\mathrm{LSD}_{\text {variety x year }}$ & \multicolumn{6}{|c|}{$\mathrm{ns}$} \\
\hline $\mathrm{LSD}_{\text {sowing date } \mathrm{x} \text { year }}$ & \multicolumn{6}{|c|}{ ns } \\
\hline $\mathrm{LSD}_{\text {variety } \mathrm{x} \text { sowing date }}$ & \multicolumn{6}{|c|}{$178.32^{*}$} \\
\hline $\mathrm{LSD}_{\text {variety } \mathrm{x} \text { sowing date } \mathrm{x} \text { year }}$ & \multicolumn{6}{|c|}{$\mathrm{ns}$} \\
\hline
\end{tabular}

The difference between the averages indicated by the same letter in the same group is not statistically significant, ":Significant difference at $\mathrm{P}<0.05$ level, ${ }^{* *}$ :Significant difference at $\mathrm{P}<0.01$ level, CV: variation coefficient, LSD: least significant difference, NS: non-significant.

Moreover, the hay yields in our study were in accordance with findings of Aka and Avcioglu (2003), in which the adaptations of alfalfa to Aegean Region conditions were examined with hay yield values for seven different alfalfa cultivars ranging from 11780.0 to $15730.0 \mathrm{~kg} \mathrm{ha}^{-1}$ with those observed in another study done under Erzurum conditions with different alfalfa cultivars (Seker, 2003), which showed the highest hay yield of $13335.0 \mathrm{~kg} \mathrm{ha}^{-1}$. Because of that the development of root and storing of spare nutrients in the root region. Thus, it is understood that the development of subsoil parts is given more importance rather than above ground ones. Despite this five cutting were performed in second year of trial and an increase was observed an increase over years (Tables 3-8). 


\section{Crude protein content}

The effect of cultivar $\mathrm{x}$ year, cultivar $\mathrm{x}$ sowing date, and cultivar $\mathrm{x}$ sowing date $\mathrm{x}$ year on the mean crude protein rates in the alfalfa cultivars sown at different dates were statistically significant at $\mathrm{p}<0.05$, and also the effect of cultivars and years were significant at $\mathrm{p}<0.01$. On the other hand, the impacts of sowing date and sowing date $x$ year were not statistically significant. Cultivars had a mean crude protein rate of $17.88 \%$ with a high value of Magnum V (18.54\%) and a low value of Nimet $(17.40 \%)$.

The mean values for the different years were 16.18, 16.60, and 20.87\%, respectively. Mean crude protein rate was the highest for all cultivars in 2017 (Table 7). Cultivar $\mathrm{x}$ year interaction was statistically significant at $\mathrm{p}<0.05$. In the cultivar $\mathrm{x}$ sowing date, the highest mean crude protein rate was $18.57 \%$ in first Magnum $\mathrm{V}$ sowing date, and the lowest rate one was observed from the third Nimet sowing date at $17.03 \%$.

Table 7. Effect of cultivar and sowing date on crude protein ratio (\%)

\begin{tabular}{|c|c|c|c|c|c|c|}
\hline \multirow{2}{*}{ Years } & \multirow{2}{*}{ Sowing dates } & \multicolumn{5}{|c|}{ Varieties } \\
\hline & & Kayseri & Magnum V & Gea & Nimet & Variety mean \\
\hline \multirow{4}{*}{2015} & $1^{\text {st }}$ sowing date & $15.86^{f-j}$ & $17.17^{\mathrm{b}-\mathrm{e}}$ & $16.47^{\mathrm{d}-\mathrm{h}}$ & $17.10^{\mathrm{b}-\mathrm{e}}$ & 16.65 \\
\hline & $2^{\text {nd }}$ sowing date & $16.57^{\mathrm{c}-\mathrm{g}}$ & $16.40^{\mathrm{d}-\mathrm{i}}$ & $15.00^{\mathrm{j}}$ & $15.23^{\mathrm{ij}}$ & 15.80 \\
\hline & $3^{\text {rd }}$ sowing date & $16.43^{\mathrm{d}-\mathrm{h}}$ & $16.53^{\mathrm{d}-\mathrm{h}}$ & $16.57^{\mathrm{c}-\mathrm{g}}$ & $14.87^{\mathrm{j}}$ & 16.10 \\
\hline & Mean & $16.28^{\mathrm{CD}}$ & $16.70^{\mathrm{C}}$ & $16.01^{\mathrm{CD}}$ & $15.73^{\mathrm{D}}$ & $16.18^{\mathrm{B}}$ \\
\hline \multirow{4}{*}{2016} & $1^{\text {st }}$ sowing date & $16.90^{\mathrm{c-f}}$ & $17.54^{\mathrm{b}-\mathrm{d}}$ & $17.55^{\mathrm{b}-\mathrm{d}}$ & $15.55^{\mathrm{g}-\mathrm{j}}$ & 16.89 \\
\hline & $2^{\text {nd }}$ sowing date & $16.06^{e-j}$ & $18.21^{\mathrm{b}}$ & $15.39^{\mathrm{g}-\mathrm{j}}$ & $16.43^{\mathrm{d}-\mathrm{h}}$ & 16.52 \\
\hline & $3^{\text {rd }}$ sowing date & $16.58^{\mathrm{c}-\mathrm{g}}$ & $17.73^{b c}$ & $15.88^{\mathrm{f}-\mathrm{j}}$ & $15.34^{\mathrm{h}-\mathrm{j}}$ & 16.39 \\
\hline & Mean & $16.51^{\mathrm{C}}$ & $17.83^{\mathrm{B}}$ & $16.27^{\mathrm{CD}}$ & $15.77^{\mathrm{D}}$ & $16.60^{\mathrm{B}}$ \\
\hline \multirow{4}{*}{2017} & $1^{\text {st }}$ sowing date & $20.54^{\mathrm{a}}$ & $21.00^{a}$ & $20.96^{\mathrm{a}}$ & $20.87^{\mathrm{a}}$ & 20.85 \\
\hline & $2^{\text {nd }}$ sowing date & $20.96^{\mathrm{a}}$ & $20.89^{a}$ & $20.80^{\mathrm{a}}$ & $20.32^{\mathrm{a}}$ & 20.74 \\
\hline & $3^{\text {rd }}$ sowing date & $21.07^{\mathrm{a}}$ & $21.38^{\mathrm{a}}$ & $20.73^{\mathrm{a}}$ & $20.88^{\mathrm{a}}$ & 21.01 \\
\hline & Mean & $20.86^{\mathrm{A}}$ & $21.09^{\mathrm{A}}$ & $20.83^{\mathrm{A}}$ & $20.69^{\mathrm{A}}$ & $20.87^{\mathrm{A}}$ \\
\hline \multirow{4}{*}{ Mean years } & $1^{\text {st }}$ sowing date & $17.77^{\mathrm{DE}}$ & $18.57^{\mathrm{A}}$ & $18.33^{\mathrm{A}-\mathrm{D}}$ & $17.84^{\mathrm{C}-\mathrm{E}}$ & 18.13 \\
\hline & $2^{\text {nd }}$ sowing date & $17.86^{\text {B-E }}$ & $18.50^{\mathrm{A}-\mathrm{C}}$ & $17.06^{\mathrm{FG}}$ & $17.33^{\text {E-G }}$ & 17.69 \\
\hline & $3^{\text {rd }}$ sowing date & $18.03^{\mathrm{A}-\mathrm{D}}$ & $18.55^{\mathrm{AB}}$ & $17.73^{\mathrm{D}-\mathrm{F}}$ & $17.03^{\mathrm{G}}$ & 17.83 \\
\hline & Mean of mean & $17.88^{\mathrm{B}}$ & $18.54^{\mathrm{A}}$ & $17.70^{\mathrm{BC}}$ & $17.40^{\mathrm{C}}$ & 17.88 \\
\hline $\mathrm{CV}(\%)$ & \multicolumn{6}{|c|}{4.08} \\
\hline LSD $_{\text {variety }}$ & \multicolumn{6}{|c|}{$0.38^{* *}$} \\
\hline $\mathrm{LSD}_{\text {sowing date }}$ & \multicolumn{6}{|c|}{$\mathrm{ns}$} \\
\hline $\mathrm{LSD}_{\text {year }}$ & \multicolumn{6}{|c|}{$0.47^{* *}$} \\
\hline $\mathrm{LSD}_{\text {variety } \mathrm{x} \text { year }}$ & \multicolumn{6}{|c|}{$0.68^{*}$} \\
\hline $\mathrm{LSD}_{\text {sowing date } \mathrm{x} \text { year }}$ & \multicolumn{6}{|c|}{$\mathrm{ns}$} \\
\hline $\mathrm{LSD}_{\text {variety } \mathrm{x} \text { sowing date }}$ & \multicolumn{6}{|c|}{$0.68^{*}$} \\
\hline $\mathrm{LSD}_{\text {variety } x}$ sowing date $x$ year & \multicolumn{6}{|c|}{$1.18^{*}$} \\
\hline
\end{tabular}

The difference between the averages indicated by the same letter in the same group is not statistically significant, ":Significant difference at $\mathrm{P}<0.05$ level, ${ }^{* *}$ :Significant difference at $\mathrm{P}<0.01$ level, CV: variation coefficient, LSD: least significant difference, NS: non-significant. 
Under different environmental conditions, different crude protein rates were observed in many studies. The values reported in the literature were from Awad and Bakri (2009) at $19.99-26.96 \%$, Geleti et al. (2014) at $18.15-19.56 \%$, Katic et al. (2009) at 17.3 - 19.7\%, Saruhan and Kusvuran (2011) at 22.67\%, Yilmaz and Albayrak (2016) at 17.37\%, Zeinab et al. (2013) at 18.5 - 23.0\%, Engin and Mut (2017) at 24.2 26.1\%, Kir and Soya (2008) at $17.86-20.26 \%$, Kir (2010) at $22.21-23.31 \%$, Saruhan and Kusvuran (2011) at $17.94-22.67 \%$, Kavut and Avcioglu (2015) at $19.83-20.11 \%$, Inal (2015) at $18.38-20.45 \%$, Yuksel et al. (2016) at $15.14-19.13 \%$, Cinar and Hatipoglu (2015) at 20.6\%, Yilmaz and Albayrak (2016) at 16.23 - 17.53\%, Avci et al. (2013) at $18.5-19.4 \%$, Turan et al. (2017) at $16.55-17.55 \%$, Strbanovic et al. (2017) at $20.00 \%$, Oten et al. (2018) at $18.39 \%$, Walie et al. (2016) at $18.06 \%$, Holman et al. (2016) at $19.50-26.50 \%$, Titei et al. (2018) at 23.00\%, Mazza et al. (2001) at 19.99 $21.70 \%$, Toricelli et al. (2001) at $19.99-21.70 \%$, Stanacev et al. (2010) at $19.70 \%$, and Scholtz et al. (2009) at $13.90-27.80 \%$.

When the values obtained in this study are compared with those above, we see that they are in accordance with some higher and some lower. The differences in crude protein rates were considered to be related to the differences among soil, cultivar, sowing date, and other environmental conditions.

\section{Crude protein yield}

Table 8 presents the statistically significant results in mean crude protein yield of the different groups. According to these results, the effect of sowing date $\mathrm{x}$ year and cultivar $\mathrm{x}$ sowing date on mean crude protein yield were statistically significant at $\mathrm{p}<0.05$, and also the effect of sowing date and year were statistically significant at $p<0.01$. On the other hand, the effect of cultivar, cultivar $\mathrm{x}$ year, and cultivar $\mathrm{x}$ sowing date $\mathrm{x}$ year were not statistically significant for crude protein yield.

The effect of sowing time on crude protein yield was statistically divided into two groups, first and second sowing time was the highest group, while the third sowing time was the lowest group. When the crude protein yield of the years is examined (Table 8). The highest crude protein yield with $3409.7 \mathrm{~kg} \mathrm{ha}^{-1}$ was obtained in 2017, while the lowest crude protein yield with $1385.7 \mathrm{~kg} \mathrm{ha}^{-1}$ was obtained in 2015 .

Nimet and Magnum $\mathrm{V}$ were in the same statistically significant groups and had the highest mean crude protein yield from their second sowing date and the lowest from the third sowing date, while Gea had the highest crude protein yield from its first and second sowing dates. These results were statistically significant at $\mathrm{p}<0.05$ for cultivar $\mathrm{x}$ sowing date.

In current study, year $\mathrm{x}$ sowing date interaction was statistically significant and was between 1385.7 and $3409.7 \mathrm{~kg} \mathrm{ha}^{-1}$. These values obtained for crude protein yield were higher than those from Inal (2015) at $881.9-1129.3 \mathrm{~kg} \mathrm{ha}^{-1}$, Turan et al. (2017) at $1348.0-2827.0$ $\mathrm{kg} \mathrm{ha}^{-1}$, Cacan et al. (2018) at $3010.0 \mathrm{~kg} \mathrm{ha}^{-1}$, and Kir and Soya (2008) at $372.5-522.3 \mathrm{~kg} \mathrm{ha}^{-1}$ and also these values were lower than those from Hansen and Krueger (1973) at 2700.0 $3250.0 \mathrm{~kg} \mathrm{ha}^{-1}$, Avci et al. (2013) at $4020.0-4220.0 \mathrm{~kg} \mathrm{ha}^{-1}$, Yilmaz and Albayrak (2016) at 3173.6 - $3837.9 \mathrm{~kg} \mathrm{ha}^{-1}$, and Engin and Mut (2017) at 3251.0 - $5906.0 \mathrm{~kg} \mathrm{ha}^{-1}$.

Even though the differences in the mean crude protein rate were not statistically significant, there were statistically significant differences in crude protein yields, which can be explained by the differences in hay yields from the cultivars and sowing years (Table 8). The correlation between increasing hay yield and crude protein content is also indicated by other researchers (Kir and Soya, 2008). 


$$
-15626-
$$

Table 8. Effect of cultivar and sowing date on crude protein yield $\left(\mathrm{kg} \mathrm{ha}^{-1}\right)$

\begin{tabular}{|c|c|c|c|c|c|c|}
\hline \multirow{2}{*}{ Years } & \multirow{2}{*}{ Sowing dates } & \multicolumn{5}{|c|}{ Varieties } \\
\hline & & Kayseri & Magnum V & Gea & Nimet & Variety mean \\
\hline \multirow{4}{*}{2015} & $1^{\text {st }}$ sowing date & 1690.4 & 1371.9 & 1740.0 & 1873.8 & $1669.0^{\mathrm{D}}$ \\
\hline & $2^{\text {nd }}$ sowing date & 1396.8 & 1507.5 & 1772.8 & 1798.2 & $1619.0^{\mathrm{D}}$ \\
\hline & $3^{\text {rd }}$ sowing date & 871.3 & 983.0 & 983.6 & 638.5 & $869.1^{\mathrm{E}}$ \\
\hline & Mean & 1319.5 & 1287.5 & 1498.8 & 1436.8 & $1385.7^{\mathrm{C}}$ \\
\hline \multirow{4}{*}{2016} & $1^{\text {st }}$ sowing date & 2443.0 & 2730.3 & 2801.9 & 2381.6 & $2589.2^{\mathrm{BC}}$ \\
\hline & $2^{\text {nd }}$ sowing date & 2437.1 & 3219.1 & 2574.7 & 2864.7 & $2773.9^{\text {В }}$ \\
\hline & $3^{\text {rd }}$ sowing date & 2604.1 & 2386.8 & 2358.0 & 2356.5 & $2426.3^{\mathrm{C}}$ \\
\hline & Mean & 2494.7 & 2778.7 & 2578.2 & 2534.3 & $2596.5^{\mathrm{B}}$ \\
\hline \multirow{4}{*}{2017} & $1^{\text {st }}$ sowing date & 3502.9 & 3379.0 & 3787.6 & 3253.8 & $3480.8^{\mathrm{A}}$ \\
\hline & $2^{\text {nd }}$ sowing date & 3027.9 & 3984.4 & 3714.2 & 3050.5 & $3444.3^{\mathrm{A}}$ \\
\hline & $3^{\text {rd }}$ sowing date & 3542.7 & 2830.9 & 3500.5 & 3341.4 & $3303.9^{\mathrm{A}}$ \\
\hline & Mean & 3358.0 & 3398.1 & 3667.4 & 3215.2 & $3409.7^{\mathrm{A}}$ \\
\hline \multirow{4}{*}{ Mean years } & $1^{\text {st }}$ sowing date & $2545.4^{\mathrm{BC}}$ & $2494.0^{\mathrm{BC}}$ & $2776.5^{\mathrm{AB}}$ & $2503.1^{\mathrm{BC}}$ & $2579.7^{\mathrm{A}}$ \\
\hline & $2^{\text {nd }}$ sowing date & $2281.0^{\mathrm{CD}}$ & $2904.0^{\mathrm{A}}$ & $2687.2^{\mathrm{AB}}$ & $2571.1^{\mathrm{A}-\mathrm{C}}$ & $2610.8^{\mathrm{A}}$ \\
\hline & $3^{\text {rd }}$ sowing date & $2339.3^{\mathrm{CD}}$ & $2067.0^{\mathrm{D}}$ & $2281.0^{\mathrm{CD}}$ & $2112.2^{\mathrm{D}}$ & $2200.0^{\mathrm{B}}$ \\
\hline & Mean of mean & 2388.6 & 2488.3 & 2581.6 & 2395.5 & 2464.0 \\
\hline $\mathrm{CV}(\%)$ & \multicolumn{6}{|c|}{14.60} \\
\hline $\mathrm{LSD}_{\text {variety }}$ & \multicolumn{6}{|c|}{ ns } \\
\hline $\mathrm{LSD}_{\text {sowing date }}$ & \multicolumn{6}{|c|}{$18.79^{* *}$} \\
\hline $\mathrm{LSD}_{\text {year }}$ & \multicolumn{6}{|c|}{$18.79^{* *}$} \\
\hline $\mathrm{LSD}_{\text {variety } \mathrm{x} \text { year }}$ & \multicolumn{6}{|c|}{ ns } \\
\hline $\mathrm{LSD}_{\text {sowing date } \mathrm{x} \text { year }}$ & \multicolumn{6}{|c|}{$32.57^{*}$} \\
\hline $\mathrm{LSD}_{\text {variety } x \text { sowing date }}$ & \multicolumn{6}{|c|}{$33.92^{*}$} \\
\hline $\mathrm{LSD}_{\text {variety } \mathrm{x} \text { sowing date } \mathrm{x} \text { year }}$ & \multicolumn{6}{|c|}{$\mathrm{ns}$} \\
\hline
\end{tabular}

The difference between the averages indicated by the same letter in the same group is not statistically significant, ":Significant difference at $\mathrm{P}<0.05$ level, ${ }^{* *}$ :Significant difference at $\mathrm{P}<0.01$ level, CV: variation coefficient, LSD: least significant difference, NS: non-significant.

\section{Acid detergent fiber $(A D F)$ rates}

According to the ADF rates in this study (Table 9), the effect of sowing date, cultivar, year, and cultivar $\mathrm{x}$ sowing date on ADF rate were statistically significant at $\mathrm{p}<0.05$, while cultivar $\mathrm{x}$ year and sowing date $\mathrm{x}$ year were statistically significant at $\mathrm{p}<0.01$; nevertheless, the effect of cultivar $\mathrm{x}$ sowing date $\mathrm{x}$ year were not statistically significant.

The lowest ADF rate at 31.99\% was observed in Magnum V cultivar and the highest was observed in Kayseri cultivar (34.78\%). When examined in terms of sowing date, the first and second sowing dates were once again in the same statistically significant group and had lower ADF rates compared with third sowing date.

Magnum $\mathrm{V}$ had always the lowest ADF rates, although Gea cultivar had the lowest ADF rate in 2017. For this reason cultivar $x$ year interaction was significant $(p<0.05)$. The effect of cultivar $x$ sowing date indicated that Magnum V's lowest ADF rate was in the second sowing date at $30.58 \%$, and that Kayseri cultivar $(35.90 \%)$ and Nimet cultivar (36.82) were the highest for ADF rate in the second sowing date and third sowing date, respectively (Table 9). 


$$
-15627 \text { - }
$$

Table 9. Effect of cultivar and sowing date on ADF (\%)

\begin{tabular}{|c|c|c|c|c|c|c|}
\hline \multirow{2}{*}{ Years } & \multirow{2}{*}{ Sowing dates } & \multicolumn{5}{|c|}{ Varieties } \\
\hline & & \begin{tabular}{|l|} 
Kayseri \\
\end{tabular} & Magnum V & Gea & Nimet & Variety mean \\
\hline \multirow{4}{*}{2015} & $1^{\text {st }}$ sowing date & 33.81 & 33.69 & 31.66 & 36.78 & $33.98^{\mathrm{BC}}$ \\
\hline & $2^{\text {nd }}$ sowing date & 37.24 & 29.71 & 35.64 & 34.60 & $34.30^{\text {в }}$ \\
\hline & $3^{\text {rd }}$ sowing date & 36.71 & 32.78 & 35.14 & 38.82 & $35.86^{\mathrm{A}}$ \\
\hline & Mean & $35.92^{\mathrm{A}}$ & $32.06^{\mathrm{DE}}$ & $34.15^{\mathrm{BC}}$ & $36.73^{\mathrm{A}}$ & $34.71^{\mathrm{A}}$ \\
\hline \multirow{4}{*}{2016} & $1^{\text {st }}$ sowing date & 33.07 & 33.40 & 30.60 & 35.27 & $33.08^{\text {B-D }}$ \\
\hline & $2^{\text {nd }}$ sowing date & 37.30 & 30.00 & 34.83 & 34.27 & $34.10^{\mathrm{B}}$ \\
\hline & $3^{\text {rd }}$ sowing date & 36.10 & 32.53 & 35.00 & 38.67 & $35.57^{\mathrm{A}}$ \\
\hline & Mean & $35.49 \mathrm{AB}$ & $31.98^{\mathrm{E}}$ & $33.48^{\mathrm{CD}}$ & $36.07^{\mathrm{A}}$ & $34.25^{\mathrm{A}}$ \\
\hline \multirow{4}{*}{2017} & $1^{\text {st }}$ sowing date & 33.53 & 32.46 & 31.53 & 32.80 & $32.58^{\mathrm{D}}$ \\
\hline & $2^{\text {nd }}$ sowing date & 33.17 & 32.04 & 32.51 & 33.28 & $32.75^{\mathrm{CD}}$ \\
\hline & $3^{\text {rd }}$ sowing date & 32.13 & 31.26 & 33.59 & 32.97 & $32.49^{\mathrm{D}}$ \\
\hline & Mean & $32.94^{\text {C-E }}$ & $31.92^{\mathrm{E}}$ & $32.54^{\mathrm{DE}}$ & $33.02^{\mathrm{C}-\mathrm{E}}$ & $32.61^{\mathrm{B}}$ \\
\hline \multirow{4}{*}{ Mean years } & $1^{\text {st }}$ sowing date & $33.47 \mathrm{DE}$ & $33.18^{\mathrm{FG}}$ & $31.26^{\mathrm{FG}}$ & $34.95^{\mathrm{BC}}$ & $33.21^{\mathrm{B}}$ \\
\hline & $2^{\text {nd }}$ sowing date & $35.90 \mathrm{AB}$ & $30.58^{\mathrm{G}}$ & $34.33^{\mathrm{CD}}$ & $34.05^{\mathrm{CD}}$ & $33.72^{\text {в }}$ \\
\hline & $3^{\text {rd }}$ sowing date & $34.98^{\mathrm{BC}}$ & $32.19^{\mathrm{EF}}$ & $34.58^{\text {B-D }}$ & $36.82^{\mathrm{A}}$ & $34.64^{\mathrm{A}}$ \\
\hline & Mean of mean & $34.78^{\mathrm{A}}$ & $31.98^{\mathrm{C}}$ & $33.39^{\mathrm{B}}$ & $35.27^{\mathrm{A}}$ & 33.86 \\
\hline $\mathrm{CV}(\%)$ & \multicolumn{6}{|c|}{4.49} \\
\hline LSD $_{\text {variety }}$ & \multicolumn{6}{|c|}{$0.82^{* *}$} \\
\hline $\mathrm{LSD}_{\text {sowing date }}$ & \multicolumn{6}{|c|}{$0.72^{* *}$} \\
\hline $\mathrm{LSD}_{\text {year }}$ & \multicolumn{6}{|c|}{$0.72^{* *}$} \\
\hline $\mathrm{LSD}_{\text {variety } \mathrm{x} \text { year }}$ & \multicolumn{6}{|c|}{$1.43^{*}$} \\
\hline $\mathrm{LSD}_{\text {sowing date } \mathrm{x} \text { year }}$ & \multicolumn{6}{|c|}{$1.23^{*}$} \\
\hline $\mathrm{LSD}_{\text {variety } \mathrm{x} \text { sowing date }}$ & \multicolumn{6}{|c|}{$1.43^{* *}$} \\
\hline $\mathrm{LSD}_{\text {variety } x} \mathrm{~s}$ sowing date $\mathrm{x}$ year & \multicolumn{6}{|c|}{$\mathrm{ns}$} \\
\hline
\end{tabular}

The difference between the averages indicated by the same letter in the same group is not statistically significant, ${ }^{*}$ :Significant difference at $\mathrm{P}<0.05$ level, ${ }^{* *}$ :Significant difference at $\mathrm{P}<0.01$ level, CV: variation coefficient, LSD: least significant difference, NS: non-significant.

The ADF values obtained in this study were higher than those of Geleti et al. (2014) at $21.49-26.19 \%$, Engin and Mut (2017) at $27.5-29.7 \%$, Toricelli et al. (2001) at 28.89 - 32.29\%, Markovic et al. (2008) at 16.3\%, and Kanani et al. (2006) at 26.50\%. In several similar studies, the ADF rates ranged from 35.16 to $36.03 \%$ (Kir, 2010) and from 31.97 to $41.5 \%$ (Gungor et al., 2008), which were higher than those from our study; however, the results of our study were in accordance with values reported by Cacan et al. (2015) at 31.86\% and Yilmaz and Albayrak (2016) at 34.50\%.

\section{Neutral detergent fiber (NDF) rates}

When the NDF rates were examined by cultivars and sowing dates, the effect of cultivar, year, and cultivar $\mathrm{x}$ sowing date were statistically significant at $\mathrm{p}<0.01$; whereas it were not statistically significant for sowing date, sowing date $\mathrm{x}$ year, cultivar $\mathrm{x}$ year, and cultivar $\mathrm{x}$ sowing date $\mathrm{x}$ year for NDF rates (Table 10). 


$$
-15628 \text { - }
$$

Table 10. Effect of cultivar and sowing date on NDF (\%)

\begin{tabular}{|c|c|c|c|c|c|c|}
\hline \multirow{2}{*}{ Years } & \multirow{2}{*}{ Sowing dates } & \multicolumn{5}{|c|}{ Varieties } \\
\hline & & Kayseri & Magnum V & Gea & Nimet & Variety mean \\
\hline \multirow{4}{*}{2015} & $1^{\text {st }}$ sowing date & 40.47 & 39.23 & 38.14 & 42.05 & 39.97 \\
\hline & $2^{\text {nd }}$ sowing date & 43.27 & 37.57 & 42.06 & 41.22 & 41.03 \\
\hline & $3^{\text {rd }}$ sowing date & 39.23 & 39.63 & 42.91 & 44.40 & 41.54 \\
\hline & Mean & 40.99 & 38.81 & 41.04 & 42.55 & $40.85^{\mathrm{A}}$ \\
\hline \multirow{4}{*}{2016} & $1^{\text {st }}$ sowing date & 38.58 & 38.33 & 39.50 & 42.27 & 39.67 \\
\hline & $2^{\text {nd }}$ sowing date & 41.33 & 37.03 & 43.33 & 41.63 & 40.83 \\
\hline & $3^{\text {rd }}$ sowing date & 37.57 & 38.87 & 41.13 & 43.77 & 40.33 \\
\hline & Mean & 39.16 & 38.08 & 41.32 & 42.56 & $40.28^{\mathrm{A}}$ \\
\hline \multirow{4}{*}{2017} & $1^{\text {st }}$ sowing date & 37.38 & 36.00 & 36.37 & 37.57 & 36.83 \\
\hline & $2^{\text {nd }}$ sowing date & 36.87 & 35.79 & 36.51 & 37.60 & 36.69 \\
\hline & $3^{\text {rd }}$ sowing date & 36.04 & 35.09 & 38.48 & 37.62 & 36.81 \\
\hline & Mean & 36.76 & 35.63 & 37.12 & 37.59 & $36.78^{\mathrm{B}}$ \\
\hline \multirow{4}{*}{ Mean years } & $1^{\text {st }}$ sowing date & $38.81^{\mathrm{CD}}$ & $37.85^{\mathrm{DE}}$ & $38.00^{\mathrm{DE}}$ & $40.63^{\mathrm{AB}}$ & 38.82 \\
\hline & $2^{\text {nd }}$ sowing date & $40.49^{\mathrm{B}}$ & $36.80^{\mathrm{E}}$ & $40.63 \mathrm{AB}$ & $40.15^{\mathrm{BC}}$ & 39.52 \\
\hline & $3^{\text {rd }}$ sowing date & $37.61 \mathrm{DE}$ & $37.86^{\mathrm{DE}}$ & $40.84^{\mathrm{AB}}$ & $41.93^{\mathrm{A}}$ & 39.56 \\
\hline & \begin{tabular}{|l|} 
Mean of mean \\
\end{tabular} & $38.97^{\mathrm{C}}$ & $37.50^{\mathrm{D}}$ & $39.82^{\mathrm{B}}$ & $40.9^{\mathrm{A}}$ & 39.30 \\
\hline $\mathrm{CV}(\%)$ & \multicolumn{6}{|c|}{3.84} \\
\hline $\mathrm{LSD}_{\text {variety }}$ & \multicolumn{6}{|c|}{$0.82^{* *}$} \\
\hline $\mathrm{LSD}_{\text {sowing date }}$ & \multicolumn{6}{|c|}{ ns } \\
\hline $\mathrm{LSD}_{\text {year }}$ & \multicolumn{6}{|c|}{$0.70^{* *}$} \\
\hline $\mathrm{LSD}_{\text {variety } x \text { year }}$ & \multicolumn{6}{|c|}{$\mathrm{ns}$} \\
\hline $\mathrm{LSD}_{\text {sowing date } \mathrm{x} \text { year }}$ & \multicolumn{6}{|c|}{$\mathrm{ns}$} \\
\hline $\mathrm{LSD}_{\text {variety } x \text { sowing date }}$ & \multicolumn{6}{|c|}{$1.41^{* *}$} \\
\hline $\mathrm{LSD}_{\text {variety } \mathrm{x} \text { sowing date } \mathrm{x} \text { year }}$ & \multicolumn{6}{|c|}{ ns } \\
\hline
\end{tabular}

The difference between the averages indicated by the same letter in the same group is not statistically significant, ":Significant difference at $\mathrm{P}<0.05$ level, ${ }^{* *}$ :Significant difference at $\mathrm{P}<0.01$ level, CV: variation coefficient, LSD: least significant difference, NS: non-significant.

Considering the different NDF rates in different cultivars, Magnum V had the lowest at $37.51 \%$, while Nimet had the highest at $40.90 \%$. In terms of sowing dates, there are two different statistically significant groups, and the lowest NDF rate was in the first sowing date group, while other sowing dates are in another group together. The NDF rates were 40.85, 40.28, and 36.78\%, respectively, for years of 2015, 2016, and 2017. The cultivar $x$ sowing date group values ranged between 36.80 and $42.93 \%$. The NDF values obtained in this study were higher than those of Kanani et al. (2006) at 34.20\%, lower than those of Kir (2010) at 42.68 - 44.13\% and Yilmaz and Albayrak (2016) at $42.20 \%$, and comparable to those of Engin and Mut (2017) at $40.0-42.9 \%$ and Geleti et al. (2014) at $36.86-43.53 \%$.

The ADF and NDF rates can be altered by environmental conditions, soil, sowing date, and cultivar. 


\section{Conclusion}

Throughout this study, domestic and foreign alfalfa cultivars obtained from various sources were sown in Siirt city of Turkey and the effect of sowing date and type of the cultivar over yield and other properties related to its agricultural value were investigated. Our results showed that the highest crude protein rate and yield, and the lowest ADF and NDF rates were founded in Magnum V cultivar. According to the sowing date mean values, the plant height, number of main stems, fresh herbage, and hay yields were higher from the first and second sowing dates on 10 March 2015 and 5 April 2015, respectively. Taken together, the most suitable dates to sow alfalfa in Siirt city of Turkey were the dates of 10 March and 5 April. Our results also showed that the Magnum V alfalfa cultivar is the best option for the production of herbage and highquality hay.

Acknowledgements. The study was supported by the Scientific Research Projects Coordinatorship of Siirt University with the project code 2014-SIUUZIR-01.

\section{REFERENCES}

[1] Aka, M. A., Avcioglu, R. (1999): Research on yield and some other yield properties of seven different alfalfa varieties in Selcuk conditions. - MSc Thesis, unpublished. Ege University, Institute of Science, Department of Field Crops.

[2] Aka, M. A., Avcioglu, R. (2003): Investigation on the yield and some other yield characteristics of seven different alfalfa varieties under Selcuk conditions. - Turkey $5^{\text {th }}$ Field Crops Congress 13-17 Oct. 2003, pp. 533-536.

[3] Avci, M. A., Ozkose, A., Tamkoc, A. (2013): Determination of yield and quality characteristics of alfalfa (Medicago sativa L.) varieties grown in different locations. Journal of Animal and Veterinary Advances 12: 487-490.

[4] Awad, O. A., Bakri, E. (2009): Effect of water quality and weeding on yield and quality of three alfalfa (Medicago sativa L.) cultivars. - Australian Journal of Crop Science 3(6): 315-321.

[5] Cacan, E., Kokten, K., Kaplan, M. (2018): Determination of yield and quality characteristics of some alfalfa (Medicago sativa L.) cultivars in the East Anatolia Region of Turkey and correlation analysis between these properties. - Applied Ecology and Environmental Research 16: 1185-1198.

[6] Cinar, S., Hatipoglu, R. (2015): Quality characteristics of the mixtures of some warm season perennial grasses with aifalfa (Medicago sativa L.) under irrigated conditions of Cukurova. - Turkish Journal of Field Crops 20: 31-37.

[7] Demiroglu, G., Geren, H., Avcioglu, R. (2008): Adaptation of different alfalfa (Medicago sativa L.) genotypes under Aegean Region conditions. - Journal of Agriculture Faculty of Ege University 45: 1-10.

[8] Eginlioglu, G., Sabanci, C. O., Bugdaycigil, M., Ozpinar, H. (1996): A study on the adaptation of some alfalfa (Medicago sativa L.) varieties to Menemen conditions. Turkey 3 rd Pasture and Forage Plants Congress, 17-19 June, Erzurum, pp. 321-327 (in Turkish).

[9] Engin, B., Mut, H. (2017): Determination of herbage yield and some quality characteristics of different alfalfa varieties. - YYU J Agr. Sci. 27: 212-219.

[10] Geleti, D., Hailemariam, M., Mengistu, A., Tolera, A. (2014): Biomass yield potential and nutritive value of selected Alfalfa (Medicago sativa L.) cultivars grown under tepid 
to cool sub-moist agro-ecology of Ethiopia. - E3 Journal of Agricultural Research and Development 4: 007-014.

[11] Gulumser, A., Bozoglu, H., Peksen, E. (2006): Research and Testing Methods. Ondokuz Mayis University, Faculty of Agriculture, Text Book (2. Press) No: 48, Samsun.

[12] Gungor, T., Basalan, M., Aydogan, I. (2008): Determination of nutrient content and metabolized energy levels in some roughages produced in Kirikkale region. - Journal of Veterinary Faculty of Ankara University 55: 111-115.

[13] Hansen, L. H., Krueger, C. R. (1973): Effect of establishment method, variety, and seeding rate on the production and quality of alfalfa under dryland and irrigation. Agron. J. 65: 755-759.

[14] Holman, J., Min, D., Klocke, N., Kisekka, I., Currie, R. (2016): Effects of irrigation amount and timing on alfalfa nutritive value. - Transactions of the ASABE 59(4): 849860.

[15] Hoy, M. D., Moore, K. J., George, J. R., Brummer, E. C. (2002): Alfalfa yield and quality as influenced by establishment method. - Agronomy Journal 94: 65-71.

[16] Inal, N. (2015): Determination of yield and quality characteristics of some alfalfa varieties under Kirsehir conditions. - MSc Thesis, Kirsehir Ahi Evran University, Institute of Science.

[17] Kanani, J., Lukefahr, S. D., Stanko, R. L. (2006): Evaluation of tropical forage legumes (Medicago sativa, Dolichos lablab, Leucaena leucocephala and Desmanthus bicornutus) for growing goats. - Small Ruminant Research 65: 1-7.

[18] Katic, S., Milić, D., Karagić, D., Vasiljević, S., Glamočić, D., Jajić, I. (2009): Variation of protein, cellulose and mineral contents of lucerne as influenced by cultivar and cut. Biotechnology in Animal Husbandry 25(5-6): 1189-1195.

[19] Kavut, Y. T., Avcioglu, R. (2015): Yield and quality performances of various alfalfa (Medicago sativa L.) cultivars in different Mediterranean environments. - Turkish Journal of Field Crops 20: 65-71.

[20] Kavut, Y. T., Celen, A. E., Demiroglu Topcu, G., Kir, B. (2014): A research on the yield and yield characteristics of some alfalfa (Medicago sativa L.) genotypes at different locations. - Journal of Agriculture Faculty of Ege University 51: 23-29.

[21] Kir, H. (2010): Determination of performance of some alfalfa varieties in Tokat-Kazova conditions. - MSc Thesis, Gaziosmanpasa University, Graduate School of Natural and Applied Sciences Department of Agronomy, Turkey.

[22] Kir, B., Soya, H. (2008): The investigation on some yield and quality characteristics of some pasture type alfalfa cultivars. - Ege University, Faculty of Agriculture, Electronic Journal 45: 11-19.

[23] Lowe, C. C., Marble, W. L., Rumbaugh, M. D. (1972): Alfalfa Adaptation, Varieties and Usage. - Amer. Soc. Agron. Inc., Madison, WI.

[24] Markovic, J., Radovic, J., Lugic, Z., Sokolovic, D. (2008): Nutritive value in leaves and stems of lucerne with advanced maturity and a comparison of methods for determination of lignin content. Proceedings of the 22nd General Meeting of the European Grassland Federation, Upsala, Sweeden. - Grassland Science in Europe 13: 480-482.

[25] Mazza, L., Schiatti, F., Torricelli, R., Veronesi, F. (2001): Quality Evaluation of Medicago Sativa Materials Belonging to the Italian Ecotype "Romagnola". - In: Delgado, I., Lloveras, J. (eds.) Quality in Lucerne and Medics for Animal Production. CIHEAM Options Méditerranéennes 45, Zaragoza, pp. 67-71.

[26] Oten, M., Kiremitci, S., Albayrak, S., Turk, M. (2018): New source populations development studies in the alfalfa (Medicago sativa L.) breeding. - Fresenius Environmental Bulletin 27: 7520-7526.

[27] Pecetti, L., Carroni, A. M., Annicchiarico, P., Manunza, P., Longu, A., Congiu, G. (2008): Adaptation, summer survival and autumn dormancy of lucerne cultivars in a south European Mediterranean region (Sardinia). - CIHEAM/FAO/ENMP/SPPF 79: 471474 . 
[28] Petkova, D., Vlahova, M., Marinova, D., Atanasov, A. (2003): Breeding evaluation of transgenic lucerne (Medicago sativa L.) lines. - Optimal Forage Systems for Animal Production and the Environment, 26-28 May, Pleven, Bulgaria.

[29] Saruhan, V., Kusvuran, A. (2011): Determination of yield performances of some lucerne cultivars and genotypes under the Southeastern Anatolia region conditions. - Ege University, Faculty of Agriculture Journal 48: 133-140.

[30] SAS Institute. (1998): INC SAS/STAT Users' Guide Release 7.0. - SAS, Cary, NC.

[31] Scholtz, G. D. J., Van Der Merwe, H. J., Tylutki, T. P. (2009): The nutritive value of South African Medicago sativa L. hay. - South African Society for Animal Science 39(1): 179-182.

[32] Seker, H. (2003): The distribution of green grass and hay yields and hay grass yields according to Kayseri and Bilensoy-80 varieties of the lines obtained from the East alfalfa. - Journal of Agriculture Faculty of Ataturk University 34: 1-7.

[33] Sengul, S., Tahtacioglu, L. (1996): Determining of hay yield and crude protein content of different alfalfa lines and cultivars under Erzurum ecological conditions. - Turkey $3^{\text {rd }}$ Grassland and Forage Crops Congress, 17-19 June 1996, pp. 608-614, Erzurum, Turkey.

[34] Stanacev, V., Dukic, D., Kovcin, S., Drinic, M., Puvaca, N., Stanacev, V. (2010): Nutritive value of the genetically divergent genotypes of lucerne (Medicago sativa L.). African Journal of Agricultural Research 5 (11): 1284-1287.

[35] Strbanovic, R., Stanisavljevic, R., Dukanovic, L., Postic, D., Markovic, J., Gavrilovic, V., Dolovac, N. (2017): Variability and correlation of yield and forage quality in alfalfa varieties of different origin. - Journal of Agricultural Sciences 23 (2017): 128-137.

[36] Titei, V., Teleuta, A. (2018): Introduction and economical value of some species of the Malvaceae family in the republic of Moldova. - Science 1 (1): 126-133.

[37] Toricelli, R., Mazza, L., Schiatti, F., Veronesi, F. (2001): Quality evaluation of Medicago sativa materials belonging to the Italian ecotype 'Romagnola'. - Centre International de Hautes Etudes Agronomiques Mediterraneennes, Zaragoza.

[38] Turan, N., Celen, A. E., Ozyazici, M. A. (2017): Yield and quality charactersstics of some alfalfa (Medicago sativa L.) varieties grown in the eastern Turkey. - Turkish Journal of Field Crops 22(2): 160-165.

[39] Walie, M., Eshetie, T., Mekonnen, W., Hunegnaw, B., Kebede, A. (2016): Dry Matter Yield, Chemical Composition and In Vitro Dry Matter Digestibility of Selected Alfalfa (Medicago sativa L.) Accessions in North Western, Ethiopia. - J. Life Sci. Biomed. 6 (3): 60-65.

[40] Yilmaz, M., Albayrak, S. (2016): Determination of herbage yield and quality of some alfalfa (Medicago sativa L.) varieties in İsparta ecological conditions. - Journal of Central Research Institute For Field Crops 25: 42-47.

[41] Yuksel, O., Albayrak, S., Turk, M., Sevimay, C. S. (2016): Dry matter yields and some quality features of alfalfa (Medicago sativa L.) cultivars under two different locations of Turkey. - Suleyman Demirel University Journal of Natural and Applied Sciences 20: 155-160.

[42] Zeinab, A. E. M., Sallam, A. M., Mohamed, N. A. (2013): Evaluating yield and quality of three alfalfa cultivars using laboratory and saline affected soil. - Journal of American Science 9(12): 5-14. 